\title{
カナダにおける環境への取り組み：将来の戦略*
}

\section{Environmental Issues in Canada: Strategies for the Future}

\author{
George H. Weyerhaeuser, Jr. \\ Weyerhaeuser Canada Ltd.
}

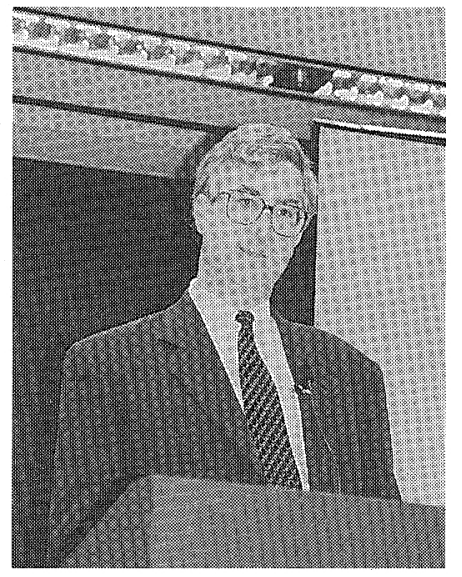

It is an honor to be invited to speak to the international session of Japan TAPPI, and a pleasure to be once again in Tokyo. TAPPI's international role in helping the pulp and paper industry to continuously improve its environmental performance is widely respected, and appreciated.

My remarks this morning will briefly summarize the current status of environmental issues in the Canadian pulp and paper industry. Its divided into five sections: First, I will review the performance of the Canadian industry as a whole. Next, we will look at Canada's regulatory climate, and issues affecting the industry. Third, we'll look at the international environmental movement, and issues currently targeted by prominent groups such as Greenpeace. Then I will share a perspective on Weyerhaeuser's strategies to address the increasing demands of environmental management. Finally, I will conclude with some observations about future frends.

(quoted from the original paper)

\section{（はじぬに）}

日本紙パルプ技術協会の国際セッションで講演する ため，招待いただき光栄であります。また，東京へ再 び来られたことは喜ばしいことであります。紙パルプ 産業の環境への対応をより良いものとするべく努力し ているTAPPIの国際的な役割は，広く尊敬さ机感謝 されています。

今日の私の講演では, カナダの紙パルプ産業におけ る最近の環境への取り組みの概要を紹介します。説明 は以下の5つのセクション分けて行います。最初に, カナダ産業の全体像について述べます。次いで, カナ

*(翻訳) 三菱製紙株式会社総合研究所 桂 徹
ダの規制状況と産業に影響を及ぼす問題について述へ ます。3 番目に，国際的な環境運動の現状とグリーン ピースのような環境保護団体が最近目標としている問 題について述べます。4 番目に，増加しつつある環境 管理への要求に対するウエアハウザー社の戦略に触れ ます。最後に, 将来の動向についての見通しで結びと します。

\section{1. カナダ紙パルプ産業の環境への対応}

過去 10 年以上にわたり, 経済変動の時期を通し， カナダ紙パルプ産業は環境をより良くするため, 総額 で 4,300 億円（36 億USドル）以上の投資を行って きた。このような変化は以下のことが原因で起こった。 ・カナダ政府や社会の要望の変化を反映した, より 


\section{綮しい規制や基準}

・海外（悪名高いヨーロッパ）の顧客からの「環境 に優しい」製品や製造プロセスに対する要望と持 続可能な管理された森林への要望

・組織化された国際的な環境保護団体の圧力

この同一の期間に, カナダ産業は用水使用量をパル プ $\mathrm{t}$ 当たり 68 立方メートルまで減少させると共に, 薬品使用量の大幅な削減を行った。排水中の TSS (全照濁固形分) は $85 \%$ 減少し, 平均 $4.1 \mathrm{~kg} / \mathrm{t}$ にな った。BOD (生物化学的酸素要求量) は現在 $3 \mathrm{~kg} / \mathrm{t}$ である。また，排水中の有機塩素量は平均で $0.9 \mathrm{~kg} /$ $\mathrm{t}$ である。ダイオキシン類とフラン類は検出されてい ない。

清浄な水と空気や持続可能な森林に対するカナ名国 民の要求は，以前にも増して高まっている。顧客，地 域社会, 従業員, 議員, 役所, 環境活動家-さらには, 長期的に安定した堅実な企業や産業に投資することを 考える株主さえも，これらを期待をしている。

環境への取り組みを行うことは，企業として活動す るための社会的なライセンスを維持する上で基本的な ことである。カナダの工場では多くのことを成しとげ たが, 他の紙パルプ生産地域においても, 同様のこと が達成されつつある。

私達が試みたことは，規制基準を科学的なものとす ること，および目標達成のために企業が最も経済性の 良い才法を取れるように柔軟性を持たせることである。 その際, 環境への取り組みを改良する新技術に投資出 来るように，国際競争力の維持にも努めなければなら ない。

究極の目標は，現在「閉鎖系 (closed loop)」技術 と呼ばれているものである。これは，1トンのパルプ や紙の生産に必要な全てのものが完全に消費されるか, 製品にされるか, 再利用されるか, 再循環されること を意味する。言い換えれば，製造亡程のいかなる副生 成物も環境に出ていかないことを表している。

過去において，カナダの製造業はしばしば，最初に， より良い環境への要求にさらされてきた。これは将来 も続くであろう。カナ多国民は環境問題に敏感であり， 国際的な活動家は，宣伝活動を北アメリカとヨーロッ パに焦点を絞って行ってきた。生産地域の中で, とく にカナダは輸出に依存するため, グリーンピースのよ うな団体が, カナダの林産品の海外での顧客を標的に すると，その成果は大きいものになる。

では, カナダ全体としての規制環境と起こりつつあ る開題について述べることにする。

\section{2. カナダの規制状況}

連邦政府と州政府で環境に関する管轄が異なるとい う点で, カナダは特徴がある。歴史的に, それぞれの 政府レベルで固有の環境規制を制定してきた。

連邦の基準は水質に関係し, 排出物, 境界を越えた 污染，および人の健康の関係するものである。一方， 州は水質と大気に大きな規制力を及ぼす。これらの政 府は, 時として重複し, 混乱し, 不必要な衝突をする。 州政府は, 私有林が $90 \%$ 占めるカナダ森林の大半 を管轄し，森林の規制と基準を決める。

今日，私達は国と企業の資源が限られた時代に生き ている。カナダ政府は, 従来の「命令して管理する (command and control)」規制が, 環境を改善する ためには必ずしも最も効果的かつ経済的であるとはい えないことに気づき始めている。むしろ, 自発的な改 善の取り組みに大きな可能性があると考えている。政 府は望ましい目標を決めるための基準が必要なことに 気がついている。その際，目標を達成するために用い る技術や資源や人材については, 企業に任されている。 近年，カナダ企業の自発的な活動を基本にした政府 の計画が, 順調な成功を修めている。「連邦政府の有 害物質減少促進計画 (ARET)」において, 紙パルプ 産業は，環境中で分解せず，生物蓄積性の特定の有害 物質を， 2000 年までに自発的に $80 \%$ 減少させること を約束した。企業は大きく進歩をした。他の例は, 2000 年までに温室効果ガスの排出を削減するという 国際的な約束をカナダが守れるよう，「カナダの自発 的な挑戦および登録 (VCR)」が民間レベルで設立さ れたことである。カナダの紙パルプ産業は積極的に協 力した。化石燃料からの二酸化炭素の排出は, 自発的 に $20 \%$ 削減され，1990 年の水準以下になった。この 削減は，エネルギー効率の向上と化石燃料からバイオ マスエネルギーへの転換により達成された。

林業の分野で，カナダは持続的な森林経営の国際基 準を採用しな最初の国である。この自発的な基準は 1996 年に採択され，カナ名標準化協会により制定さ れた。これにはISOを基にした手順が必要とされ， 製造業者以外に, 学界, 政府, 消費者団体, 先住民 (Aboriginal people), 環境保護団体, 労働組合が参 加した。種々の企業や団体が新しい森林基準の履行へ の関与を表明した。産業界は, 基準を達成するためど のような協力が出来るか, 州政府と検討中である。

法律の制定と規制は産業の環境活動と環境への投資 に引き続き影響を与えるが, 自発的な活動と報償金付 きの基準により, カナダはより経済性のある方法で環 
境を改善してゆくものと考えられる。

次に, 国際的な環境保護運動における最近の課題と, そのカナダ産業への影響について述べる。

\section{3. 国際的な環境運動の流れとカナダの対応}

カナダでは，国際的な「グリーン」運動が，規制活 動の課題に大きな影響を及ぼしている。私達は, 環境 活動家の運動により，污染の減少と森林管理に関する 多くの変化が産業側に生じたことを, 時々認めざるを 得ない。

紙パルプ製造業は，工場排出物の減少から，製品の 無塩素化, 伐採作業の変更, 生態系の保護, 新なな保 護地域の設定までと，あらゆる宣伝の標的にされてき た。カナダの州，とくにブリティッシュ・コロンビア 州では，広大な森林が公園内で永久に保護されること になった。

経験が豊富で財政的に安定した，永続的な「番犬」 を相手にしていることを，私達は今や産業として認識 している。環境運動は制度化され国際化されている。 これら活動家は宣伝媒体を熟知し, 話題性を作り出す 優れた才能を持っている。さらに重要なことは，情報 を共有したり，支持者を集めたり，戦略を統合するた め, 徐々にコンピュータネットワークを利用した地球 規模での活動を始めていることである。

カナダでの経験から，活動家は顧客，消費者，市民， 役人，議員，さらには投資家を卷き込んで，企業の活 動とその社会への影響に対し, 効果的な問題提起を行 うことが明らかになっている。

環境連動の凬辺には，もっと極端な見方をする人々 がいる。彼らは, 産業的な森林経営をなくすことや, 紙パルプ製㣍の使用を大きく減少させることまで主張 している。

年脜予算が 180 億円（1.5 億米ドル）と世界最大の 環境保護団体であるグリーンピースは，現在，国際的

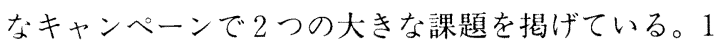
つは痤業的な森林経営である。当初の標的を, 北米北 西部の温带雨林中における原生林の伐採に置いている。

グリーンピース草案の第 2 の課題は, 地球温暖化と 温公効果ガスの削減であり，これらも結果として紙パ ルプ産業を標的にしている。

誠垁な環境連動家は, 最終の目標と実際的な解決策 を明らかにするため, 産業と共に活動を始めているよ うである。カナダの近年の世論調査では，環境保護団 体への支持は明らかに低下傾向にある。グリーン活動 家への信頼性の低下は，林道の封鎖，木の損傷，その 他の規則違反に見られるような，過激な団体が用いた
戦術の結果である。

今年の夏, グリーンピースによる $\mathrm{BC}$ 州沿岸地域の 森林保護キャンペーンは, 労働組合, 地域社会, 政府, および先住民の指導者により批判された。これらのこ とから，私は企業が行ってきた環境改善への取り組み を，カナダの国民が認め支持していると確信している。 国民は話合いと合意に基づいた解決を願っている。私 達の産業が, 公開討論において優利な立場に立つチャ ンスは十分に存在する。

このような変化の結果, 新たな企業戦略の段階にな つた。私達は穏健な環境活動家に協力する必要がある。 私達は討論における攻撃を和らげ, 善意の環境活動家 への批判をやめる必要がある。両者の架け橋を造るこ とにより，産業による自発的な規制や自主的な基準を 国民が受け入れる下地が出来ると考える。

今日，私達は以前にも増して，主な関係者の意見を 聞き, 理解し, 環境への取り組みをそれに合わせる必 要がある。私達が責任ある企業であることを示さなけ ればならない。経済的に実現可能であり，環境に貢献 し，社会的に受容される解決策を見つけるためには， 国民と理性的な話合いをする必要がある。

インターネットで世界の環境運動家による情報交換 の様子を見た人が，アジアの顧客や消費者の関心も高 まりつつあると報告している。この地域は，林産製品 の不買運動を進めようとする活動家の標的にされるか もしれない。事実, 西ヨーロッパの戦術的な環境活動 家を世界の他の地域へ「輸出」しようとしている。

もし，過去のカナダが環境に関する討論や活動の 「中心」であったとするならば, 今後現象は拡散し, 異なった形で現れるかもしれない。そのような場合に は，カナ正企業が得た教訓は役に立つかもしれない。 国境を越えて企業が協力する（学んだことや経験を共 有する）良い機会であるように思われる。

終わりにあたり，ウエアハウザー社がこれらの変化 に対応して行っているいくつかの方策について述べる。

\section{4. ウエアハウザー社が環境への取り組みを改善 するために率先して行っていること}

ウエアハウザー社では, 将来の「理想的な」紙パル プ製造設備は，環境を破壊するような物質を排出する ものであってはならないと考えている。科学技術によ りそれは可能である。

理想に至るまでは，環境に及ぼす影響が最小の生産 （MIM）を目指す。このために生産の全ての段階を見 值す。

・原料, 薬品, 水, エネルギーの使用を最小にする 
・廃棄物を減少させ, 最小にするため再利用する

・漏洩をなくすため信頼性の高い製造プロセスにす る

・有害な廃呆物を適正に処理する

・従来は埋め立てられていた物を回収, 再利用する 私達の施設が全ての法律や規制を守り続けることを 誓う。私達は, 变化しつつある要求に応えられるよう に工場を改良し続ける。その際, 効果的に環境対策費 を使用する。

私達の主たる任務および存在の理由は, 顧客の要望 や要求に応じた林産製品を, 利益を得つつ製造するこ とである。私達が努力すべきことは，環境に関する出 費を「費用」から「投資」へと変えることである。要 するにこれろの出費を環境へと同様に収益へのプラ スの効果にすることである。

今年の始めにミネアポリスで開催されたTAPPIの 環境会議で, ウエアハウザー社会長の Jack Creightonは，環境への「全身的な (holistic)」取り組みを 提案した。Jackは, 私同様, 総合的な取り組みによ って, 環境, 社会, 顧客, 経済性を調和させることが 出来ると考えている。ウエアハウザー宣言にはこのこ とが盛り込まれている。

・責任ある森林管理（米国の私有林，カナダの国有 林)

・製品の品質を最高に維持しつつ, 廃棄物を最小に する清浄で効率的な生産

・企業の長期存続を確実にする持続可能な財政状態 環境対応の経済性と企業の存続に関し，何らの迷い も感じてない。財政的な成功なくして環境的な優秀さ はありえないからである。

\section{5. 結 び}

カナダの紙パルプ産業の環境への取り組みをまとめ ると,以下のようである。

産業によって生じる排出物や廃葉物は, 明らかに減 少する傾向にある。カナ名政府は結果に注目しており， 達成に対する報償金が付いた基準や，産業による自発 的な数值目標を受け入れるようになってきている。輸 出依存の林業経済でもあり, また過去十年間激しい論
争を行ったこともあり, 組織化された国際的な環境運 動による変化を求める圧力と要求に対抗することを通 じて，カナダの産業は良くなってきた。カナダ国民の 考え方も, 過激な環境活動家の戦術を排除するまで穞 健になってきた。

この結果, 新しい産業戦略を考える機会が生じた。 それは，穞健な環境活動家に手をさしのべ，同盟関係 を築くこと，共通の土俵を見つけることである。カナ ダの産業と世界の他の地域の紙パルプ産業にとって, まだ課題は残っている。

私達の顧客, 政府, 社会は, 森林伐採が環境に影響 を及ぼさないこと, 製品や製造工程からの排出物が環 境に優しくなることを, 期待している。環境保護団体 は世界的に連携し, 資金を集める機会を求めて新しい 市場で宣伝活動を繰り広げている。とくに, 紙パルプ の需要と生産の両方が急成長しているアジアにおいて。

結論として, 以下のような信念に基づいて環境への 取り組みが行われるならば，将来は良くなるであろう と，私は環境問題を楽観的に見ている。

第一に, 私達は事業を改善し, 理解を深め, 生産が 環境へ及ぼす影響を和らげるように努める。

第二に, 私達は世界中の人々が必要とし望む製品を 製造することにより，繁栄と利益を得続ける。

第三に, 私達の顧客, 消費者, 従業員, 地域社会, 政府, 投資家は, 私達が持続可能で, 再生可能で, 再 利用可能な製品を創造する真の「グリーン」産業であ ることを認めるであろう。

グリーンピース・インターナショナル前代表の Paul Gildingは，かつて「21世紀の環境活動におけ る真の指導力は, 産業界から生じるであろう」と言っ ている。彼は正しいと思う。

紙パルプ産業の指導者として, 私たちの産業と環境 への取り組みに対する理解を深めるため, 同僚, 顧客, 消費者, 政府の役人, 投資家, 環境活動家の中にいる 潜在的な仲間達と共に, 全ての局面で率先して活動し なければならない。もし私達がこのような方針で進め るならば, カナダおよびその他の地域において, 将来, 堅実で, 利益が上がる永続的な事業を築くことが出来 るであろう。 